dr inż. Marek Sobaś

Instytut Pojazdów Szynowych ,TABOR”

\title{
Wózek 33MN do oczyszczarki tlucznia OT-84
}

\begin{abstract}
$W$ artykule przedstawiono opis trzyosiowego wózka napędnego 33MN dla oczyszczarki thucznia OT-84. W artykule przedstawiono konstrukcje układu biegowego, która jest rozwiazaniem innowacyjnym i pierwszym tego typu w kraju. Zaprezentowano podstawowe węzły konstrukcyjne wózka $33 M N$.
\end{abstract}

\section{Wstęp}

W latach $2009 \div 2012$ konstruowano w IPS „Tabor” wózek „33MN” dla oczyszczarki thucznia „OT-84” na potrzeby PKP PLK S.A. Wykonawca oczyszczarki oraz ww. wózków był Zakład Pojazdów Szynowych w Stargardzie Szczecińskim. Opracowanie dokumentacji konstrukcyjnej wózka napędnego typu $33 \mathrm{MN}$ zlecono IPS „Tabor” w Poznaniu. Ponieważ masa oczyszczarki jest większa niż 90 ton, a dopuszczalny nacisk zestawu kołowego na tor wynosi 22,5 tony dla klasy toru jedynym rozwiązaniem było wyposażenie pojazdu w układy biegowe trzyosiowe. Zakładając, że dopuszczalny nacisk zestawu kołowego na tor, wynosi 20 ton, masa własna oczyszczarki wraz z tłuczniem może wynosić nawet 120 ton. W związku z powyższym przed konstruktorami IPS „Tabor” postawiono zadanie, aby opracować koncepcję oraz dokumentację konstrukcyjną wózka trakcyjnego, który nazwano „33MN”. Początkowa koncepcja, aby rozwiązanie wózka oprzeć na istniejących wózkach wagonów towarowych typu ,7TN” oraz ,7TNa” z reso- rami piórowymi, uległa zmianie wskutek sugestii wymagań klienta, aby zawieszenie pierwszego stopnia stanowiły sprężyny śrubowe pierwszego stopnia wraz $\mathrm{z}$ thumikiem ciernym, analogicznie jak w standardowym wózku dwuosiowym Y25.

\section{Koncepcja wózka}

\subsection{Opis techniczny oczyszczarki}

Koncepcja wózka „33MN” została opracowana w oparciu o założenia konstrukcyjne oczyszczarki OT-84, które zostały zamieszczone w opracowaniu Zakładu Pojazdów Szynowych w Stargardzie Szczecińskim [9]. Oczyszczarka thucznia jest samojezdna, całkowicie hydrauliczną maszyną torowa, przeznaczoną do czyszczenia pełnej warstwy podsypki tłuczniowej bez naruszania konstrukcji toru w procesie technologicznym naprawy głównej lub średniej na liniach: magistralnych, pierwszorzędnych i drugorzędnych. Praca maszyny polega na wybieraniu podsypki thucz- 
niowej $\mathrm{z}$ nawierzchni kolejowej bez naruszania konstrukcji toru, odsianiu zanieczyszczeń z wybranej podsypki, wprowadzeniu oczyszczonego tłucznia z powrotem na tor, a zanieczyszczenia na specjalne środki transportowe. Do zasilania całej maszyny służy siłownia z silnikiem spalinowym typu „Caterpillar” z dzielnikiem momentu, pompami hydraulicznymi, sprężarka, zbiornikiem oleju hydraulicznego, układami silnika i częściami układu hydraulicznego. Z siłowni za pomocą układu hydraulicznego następuje przesyłanie oleju hydraulicznego do napędów zespołów roboczych maszyny i układu ruchów wstępnych znajdujących się na obu stronach maszyny. Sterowanie pracą silnika i wszystkich układów: hydraulicznego i pneumatycznego jest realizowane zdalnie za pomocą układu elektronicznego ze sterownikiem mikroprocesorowym. Podsypka thuczniowa jest wybierana przez mechanizm wybierakowy podczas wolnej jazdy roboczej. Jest to mechanizm $\mathrm{z}$ łańcuchem wybierakowym pracującym $\mathrm{w}$ obwodzie zamkniętym po spięciu go $\mathrm{z}$ torem $\mathrm{i}$ zmontowaniem belki podtorowej. Transportowana przez łańcuch mechanizmu wybierakowego na maszynę podsypka thuczniowa jest rozrzucana na sita przesiewacza wibracyjnego. Na przesiewaczu następuje oddzielenie zanieczyszczeń od wybieranej podsypki. Odsiewki z przesiewacza są odbierane przez zespół dwóch przenośników taśmowych, składający się z przenośnika stałego i wychylnego. Przenośnik wychylny znajduje się nad kabiną „” i ma za zadanie wyrzucić odsiewki na bok, poza torowisko lub do przodu na specjalne wagony. Natomiast oczyszczony tłuczeń $\mathrm{z}$ przesiewacza jest odbierany przez zsyp tłucznia i kierowany bezpośrednio na tor lub na przenośniki taśmowe rozścielające. Podsypka wprowadzona z powrotem na tor jest profilowana przez pług znajdujący się tuż za zsypem thucznia. Mechanizm podnoszący, znajdujący się na maszynie umożliwia podnoszenie toru w przypadku zbyt małej grubości podkładki i pod podkładami oraz nasuwanie w planie w celu odsunięcia od przeszkód. Oczyszczarka typu OT-84.00 wyposażona jest $\mathrm{w}$ rejestrator oraz układ automatyczny bezpieczeństwa ruchu. W skład automatyki bezpieczeństwa wchodzą: system SHP (samoczynne hamowanie pociagu), CA (czuwak aktywny) oraz RADIO-STOP.

\subsection{Opis wózka trzyosiowego $33 \mathrm{MN}$}

Wózek trzyosiowy 33MN jest wózkiem trakcyjnym, przeznaczonym do specjalistycznych zespolów trakcyjnych, jak np. wspomniana oczyszczarka thucznia OT-84 i posiada pewne cechy, zaczerpnięte ze standardowych wózków wagonów towarowych. Do takich cech można zaliczyć:

- oparcie nadwozia na wózku za pomocą czopa kulistego oraz ślizgów bocznych sprężystych z powiększonymi luzami pionowymi $20 \pm 1 \mathrm{~mm}$, dopasowanymi do zwiększonej bazy oczyszczarki; luzy ślizgów bocznych w wózkach standardowych typu Y25 wynoszą $12 \pm 1 \mathrm{~mm}$

- rozwiązanie węzła maźnicznego, zwłaszcza korpusu maźnicy, usprężynowania oraz tłumika ciernego,

- rozwiązanie uziemienia wózka za pomocą przewodu ochronnego zgodnego z kartą UIC 533 [4].

Wózek 33MN z podziałem na podzespoły i elementy jest przedstawiony na rys. 1 .

\subsection{Parametry techniczne oczyszczarki}

Szerokość toru $.1435 \mathrm{~mm}$

Długość ze zderzakami............................................29644 mm

Rozstaw osi skrajnych........................................25 $550 \mathrm{~mm}$

Baza pojazdu (odległość pomiędzy środkami czopów skrętu)..............22350 mm

Szerokość maksymalna............................................. $3100 \mathrm{~mm}$

Wysokość maksymalna............................................4600 mm

Maksymalna prędkość transportowa $\mathrm{z}$ własnego napędu na torze prostym.....80 km/h

Maksymalna prędkość transportowa obcym środkiem trakcyjnym.............100 km/h

Minimalny promień łuku toru, przez który może przejechać pojazd.............150 m

Moc silnika trakcyjnego..............................................653 kW

Przeniesienie napędu.........................................hydrostatyczne

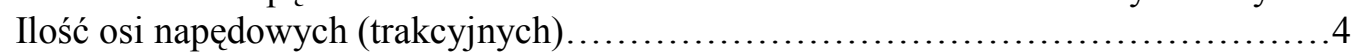

Całkowita ilość osi ...........................................................

Średnica toczna kół..................................................920 mm

Hamulec zespolony .............................................typu Oerlikon

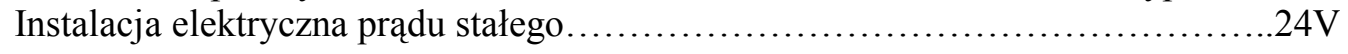

Masa całkowita ........................................................ 100 ton 


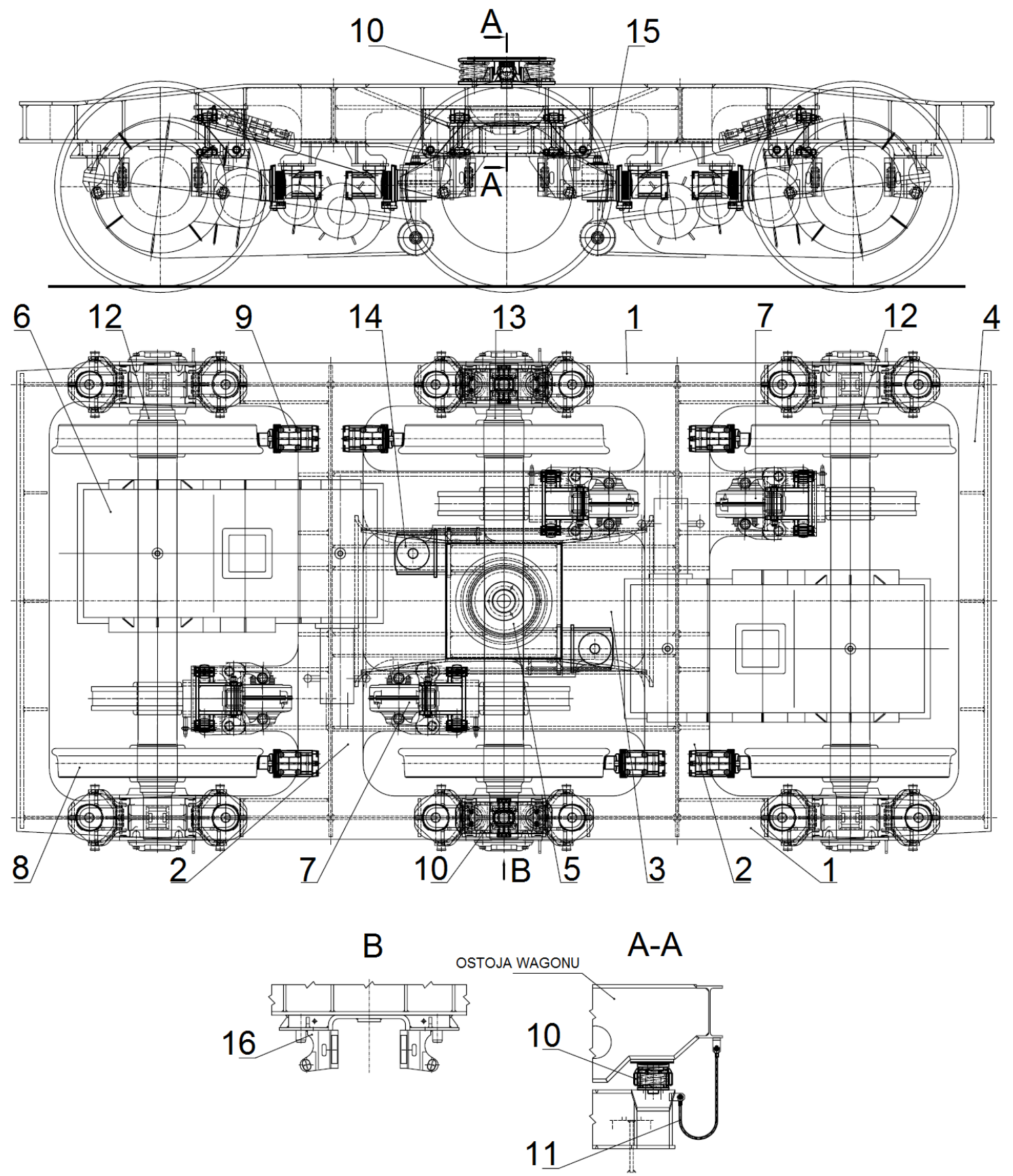

\section{Legenda:}

1 -ostojnica, 2 - poprzecznica, 3 - podtużnica, 4-czolownica, 5 - gniazdo skrętu, 6 - przektadnia trakcyjna, 7 - mechanizm zaciskowy hamulca tarczowego, 8 - zestaw kołowy, 9 - klocek czyszczqcy, 10 - ślizg boczny, 11 - przewód uziemiajacy, 12 oś skrajna napędna, 13 - oś środkowa toczna, 14 - wspornik powieszenia przekładni, 15 - cięgło podwieszenia przekładni, 16 - korpus prowadnicy 


\begin{tabular}{|c|c|}
\hline Parametr & Wartość \\
\hline Szerokość (prześwit) toru & $1435 \mathrm{~mm}$ \\
\hline Długość wózka & $4500 \mathrm{~mm}$ \\
\hline Szerokość wózka & $2302 \mathrm{~mm}$ \\
\hline $\begin{array}{l}\text { Rozstaw ślizgów bocznych sprę- } \\
\text { żystych }\end{array}$ & $2000 \mathrm{~mm}$ \\
\hline $\begin{array}{l}\text { Rozstaw sąsiednich zestawów } \\
\text { kołowych }\end{array}$ & $1600 \mathrm{~mm}$ \\
\hline $\begin{array}{l}\text { Rozstaw skrajnych zestawów } \\
\text { kołowych (baza wózka) }\end{array}$ & $3200 \mathrm{~mm}$ \\
\hline $\begin{array}{l}\text { Rozstaw środków maźnic zesta- } \\
\text { wów kołowych }\end{array}$ & $2000 \mathrm{~mm}$ \\
\hline $\begin{array}{l}\text { Gniazdo kuliste skrętu (promień } \\
\text { gniazda skrętu) }\end{array}$ & $190 \mathrm{~mm}$ \\
\hline $\begin{array}{l}\text { Wysokość środka kuli gniazda } \\
\text { skrętu od główki szyny }\end{array}$ & $950_{-5}^{+3} \mathrm{~mm}$ \\
\hline $\begin{array}{l}\text { Wysokość płyty oporowej czopa } \\
\text { skrętu od poziomu główki szyny }\end{array}$ & $880 \pm 5 \mathrm{~mm}$ \\
\hline $\begin{array}{l}\text { Maksymalny nacisk zestawu ko- } \\
\text { łowego na tor }\end{array}$ & $20 \mathrm{t}(196,2 \mathrm{kN})$ \\
\hline $\begin{array}{l}\text { Minimalny promień łuku toru } \\
\text { (warsztatowy), przez który może } \\
\text { przejechać pojazd na wózkach }\end{array}$ & $75 \mathrm{~m}$ \\
\hline $\begin{array}{l}\text { Maks. przesuw poprzeczny ramy } \\
\text { wózka względem maźnicy na } \\
\text { stronę }\end{array}$ & $\pm 15 \mathrm{~mm}$ \\
\hline $\begin{array}{l}\text { Maks. przesuw wzdłużny ramy } \\
\text { wózka względem maźnicy na } \\
\text { stronę }\end{array}$ & $8 \div 10 \mathrm{~mm}$ \\
\hline Całkowita liczba osi & 3 \\
\hline $\begin{array}{l}\text { Ilość osi trakcyjnych (napędo- } \\
\text { wych) }\end{array}$ & 2 \\
\hline \multirow[b]{2}{*}{ Hamulec } & tarczowy \\
\hline & $\begin{array}{l}\text { bloki czyszczące } \\
\text { TCU Nr 240002- } \\
100 \text { SAB WABCO }\end{array}$ \\
\hline $\begin{array}{l}\text { Tarcza hamulcowa (średnica ze- } \\
\text { wnętrzna×średnica } \\
\text { piasty×szerokość wieńca) }\end{array}$ & $\varnothing 610 / 320 \times 110 \mathrm{~mm}$ \\
\hline Ilość osi hamowanych & 3 \\
\hline Osie trakcyjne & 2 tarcze hamulcowe \\
\hline
\end{tabular}

\begin{tabular}{|c|c|}
\hline $\begin{array}{l}\text { Średnica okręgu tocznego kół w } \\
\text { stanie nowym }\end{array}$ & $\varnothing 920 \mathrm{~mm}$ \\
\hline $\begin{array}{l}\text { Dopuszczalne zużycie kół (liczone } \\
\text { na promieniu) }\end{array}$ & $30 \mathrm{~mm}$ \\
\hline $\begin{array}{l}\text { Minimalna średnica toczna koła } \\
\text { monoblokowego po ostatnim } \\
\text { przetoczeniu profilu }\end{array}$ & $\varnothing 870 \mathrm{~mm}$ \\
\hline $\begin{array}{l}\text { Minimalna dopuszczalna średnica } \\
\text { toczna koła monoblokowego }\end{array}$ & $\varnothing 860 \mathrm{~mm}$ \\
\hline Czop osi zestawu kołowego & $\varnothing 130 \times 217 \mathrm{~mm}$ \\
\hline Łożyska osiowe & $\begin{array}{c}\mathrm{NJ}+\mathrm{NJP} \\
130 \times 240 \times 80\end{array}$ \\
\hline Usprężynowanie & $\begin{array}{l}\text { za pomocą sprężyn } \\
\text { śrubowych, } \\
\text { jednostopniowe bez } \\
\text { charakterystyki } \\
\text { progresywnej }\end{array}$ \\
\hline Miękkość usprężynowania wózka & $\begin{array}{c}0,1224 \mathrm{~mm} / \mathrm{kN}= \\
1,211 \mathrm{~mm} / \mathrm{t}\end{array}$ \\
\hline Sztywność usprężynowania wózka & $\begin{array}{c}8,169 \mathrm{kN} / \mathrm{mm}= \\
0,825 \mathrm{t} / \mathrm{mm}\end{array}$ \\
\hline Ślizgi boczne & sprężyste \\
\hline $\begin{array}{l}\text { Luz pionowy na ślizgach } \\
\text { bocznych sprężystych }\end{array}$ & $20 \pm 1 \mathrm{~mm}$ \\
\hline Masa wózka & $10400 \mathrm{~kg}$ \\
\hline $\begin{array}{l}\text { Zarys wózka spełnia wymagania } \\
\text { karty UIC 505-1 [1] }\end{array}$ & $\begin{array}{l}\text { jak dla pojazdów } \\
\text { trakcyjnych }\end{array}$ \\
\hline
\end{tabular}

\subsubsection{Rama wózka}

Wózek posiada ramę zamkniętą. Konstrukcja ramy wózka jest całkowicie spawana i składa się z następujących zasadniczych elementów (rys.2):

- dwóch ostojnic (poz.1),

- dwóch poprzecznic (poz.2),

- belki środkowej (poz.3),

- dwóch czołownic (poz.4).

$\mathrm{Na}$ elementy nośne ramy zastosowano stal S355J2 (o wytrzymałości na rozciąganie $\mathrm{R}_{\mathrm{m}}=510 \div 680$ $\mathrm{MPa}$ oraz granicy plastyczności $\mathrm{R}_{\mathrm{e} \text { min }}=355 \mathrm{MPa}$ ). Ostojnice i poprzecznice mają przekrój dwuteowy z wzmocnieniami w postaci żeber. Czołownice mają przekrój ceowy. Ostojnice są połączone dwoma poprzecznicami (poz.2). Poprzecznice połączone są z belką środkową (poz.3), w której znajduje się gniazdo skrętu z wkładką z tworzywa sztucznego (poz.5). Do poprzecznic (poz.2) są przyspawane wsporniki do 
mocowania mechanizmów zaciskowych hamulca tarczowego (poz.7) i wsporniki mocowania bloków czyszczących (poz.9). Do belki środkowej (poz.3) przyspawane są wsporniki do mocowania dźwigni łączącej przekładnię trakcyjną. Na ostojnicach znajdują się otwory do mocowania ślizgów bocznych sprężystych (poz.10). Do ostojnic wózka są przyspawane wsporniki do mocowania bloków czyszczących koła (poz.18) oraz korpusy prowadnic (poz.14), mających za zadanie prowadzenie zestawu kołowego w trakcie jazc

\subsubsection{Zawieszenie pierwszego stopnia}

Wózek posiada zawieszenie jednostopniowe na sprężynach śrubowych (poz.4) bez charakterystyki progresywnej. Rama wózka spoczywa na 6-ciu maźnicach (poz.8) za pośrednictwem 12-stu kompletów sprężyn śrubowych. Sprężyna wewnętrzna wykonana jest z pręta $\phi 20 \mathrm{~mm}$, sprężyna zewnętrzna z pręta ф32 mm. Sprężyny wykonane są ze stali 52CrMoV4+HH zgodnie z normą EN 10089:2002 [7]. Sprężyna zewnętrzna jest prawozwojna, natomiast sprężyna wewnętrzna jest lewozwojna.
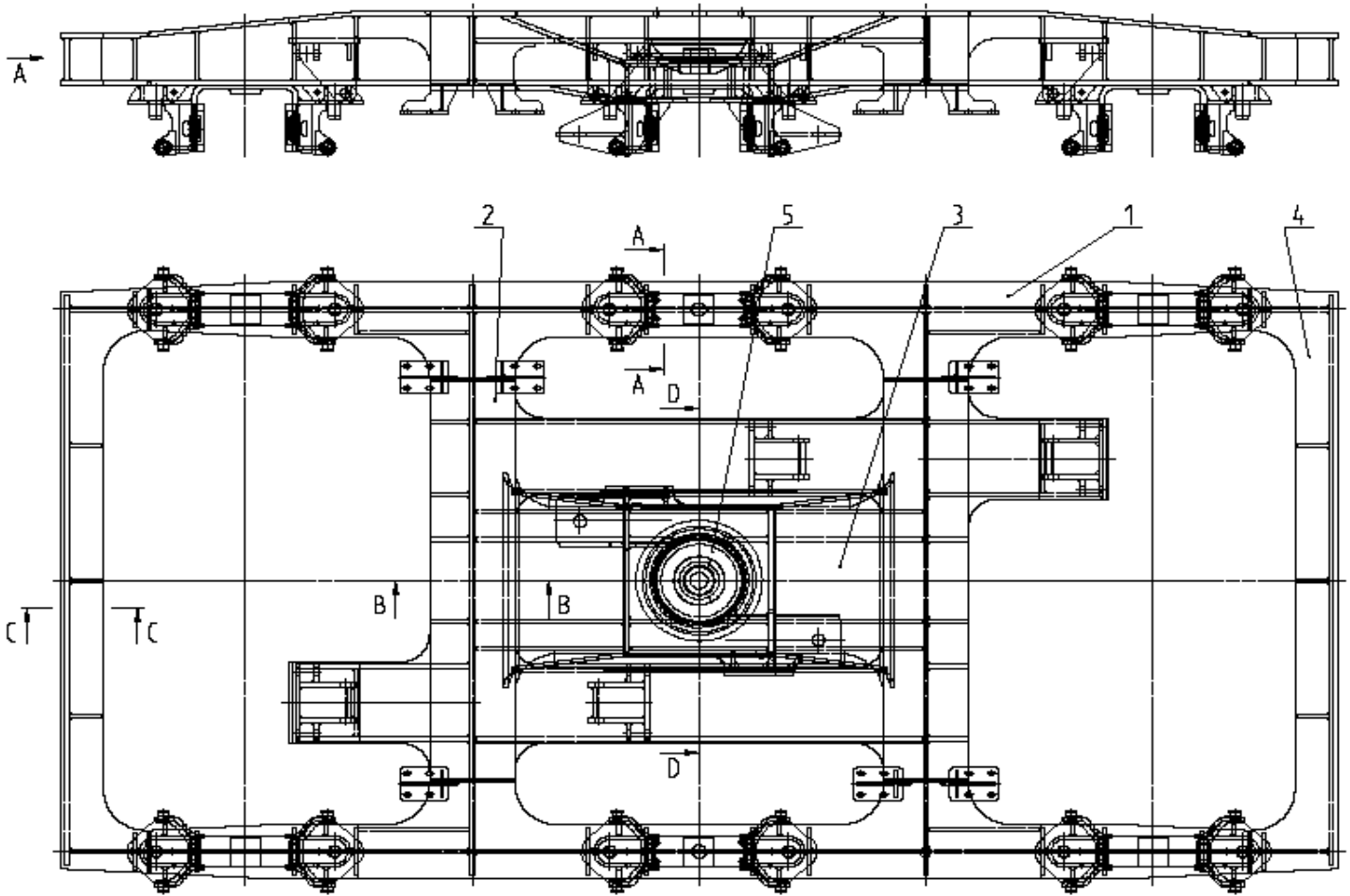

A
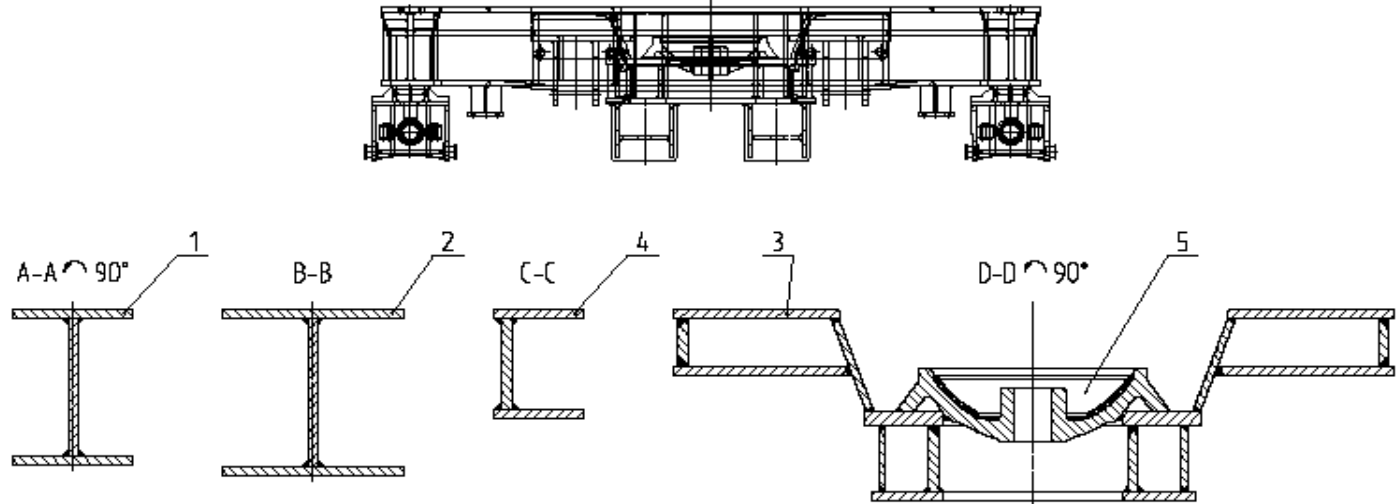

1 - ostojnica

2 - popгzecznica 3 - podłużnica

4 - czolownica 5 - griazdo skretu 
Zawieszenie jest tak skonstruowane, że umożliwia:

- ruchy wzdłużne $\mathrm{L}_{1}= \pm 9 \mathrm{~mm}$ maźnicy zestawu kołowego względem ramy wózka,

- ruchy poprzeczne $\mathrm{L}_{2}= \pm 15 \mathrm{~mm}$ maźnicy zestawu kołowego względem ramy wózka (rys.4).

Ruchy wzdłużne $\mathrm{z}$ luzem $\mathrm{L}_{1}= \pm 9 \mathrm{~mm}$ umożliwiają quasi-radialne ustawianie osi zestawu kołowego w łuku toru o promieniu $\mathrm{R}_{\min }=180 \mathrm{~m}$, co zmniejsza katy nabiegania koła na szynę i zużycie wieńców kół (obrzeży i powierzchni tocznych). Luzy poprzeczne $\mathrm{L}_{2}$ $= \pm 15 \mathrm{~mm}$ umożliwiają wpisywanie się pojazdu wszystkich zestawów kołowych pojazdu w łuki toru, zwłaszcza o minimalnym promieniu. $(\mathrm{R}=75 \mathrm{~m})$. Ma to bardzo istotne znaczenie ze względu na przesuwność osi środkowej względem ramy wózka. Przesuwność osi środkowej zwiększa bezpieczeństwo jazdy pojazdu przez tory wichrowate $\mathrm{w}$ warunkach quasi-statycznych.

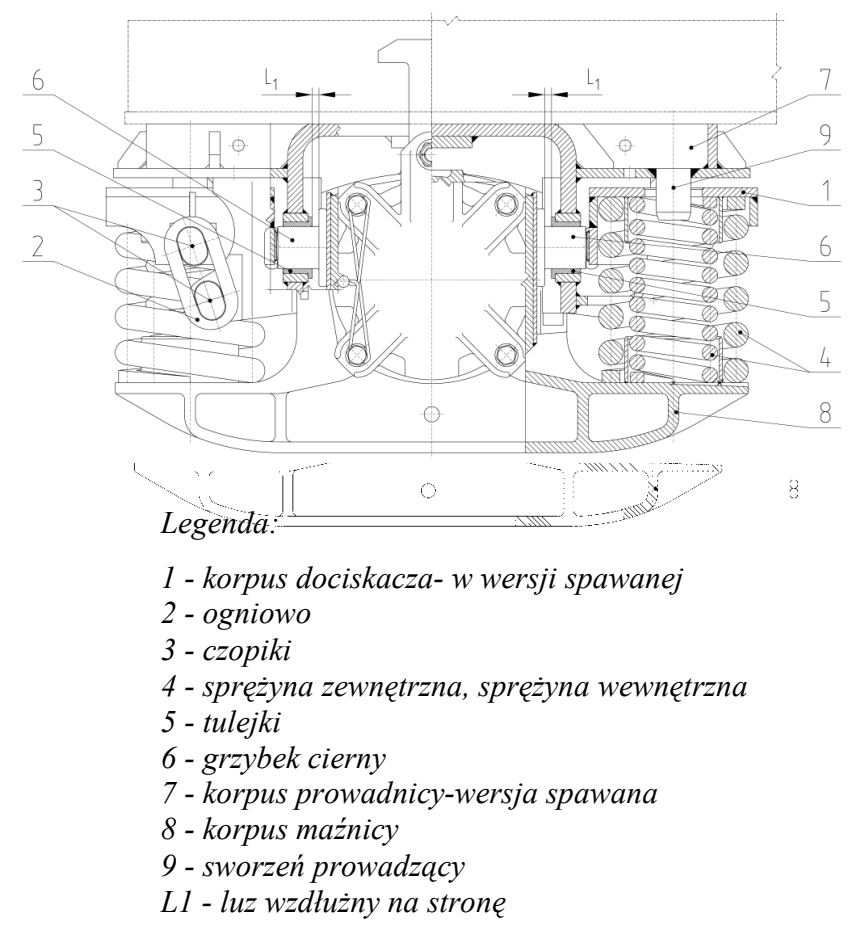

Rys.3 Widok z boku usprężynowania pierwszego stopnia wózka $33 \mathrm{MN}$

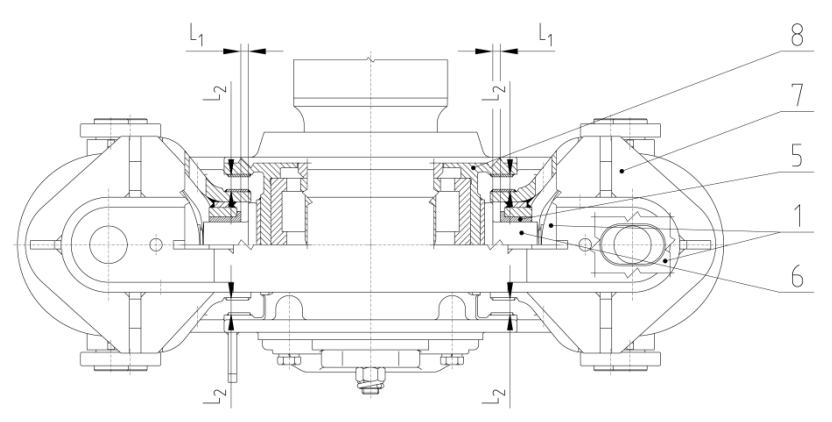

Legenda:

1 - korpus dociskacza

5 - tulejka

6 - grzybek cierny

7 - korpus prowadnicy
8 - korpus maźnicy

L1 - luz wzdtużny na strone

L2 - luz poprzeczny na stronę

Rys.4. Zawieszenie pierwszego stopnia wózka 33MN - rzut z góry

\subsection{3. Ślizgi boczne sprężyste}

Wózki są wyposażone w ślizgi sprężyste. Ślizgi składają się ze spawanego korpusu ślizgu i prowadnicy wykonanych ze stali S355J2.

$\mathrm{Na}$ korpusach naspawane są płytki o grubości $5 \mathrm{~mm}$ wykonane ze stali manganowej wg karty UIC 893 kategoria E [4]. Wykładziny ślizgów bocznych sa wykonane $\mathrm{z}$ tworzywa bezazbestowego i spełniaja wymagania programu OW-1221, będącego thumaczeniem dokumentu ORE/ERRI nr 12040005 [8]. Zadaniem tych ślizgów jest wywoływanie stałego momentu tarcia tłumiącego drgania wężykowanie wózków. Ślizgi boczne mogą być wykonane w dwóch wariantach. Wybór wariantu pozostawia się producentowi pojazdu. Wariant I ślizgu jest przedstawiony na rys. 5.

Wariant I składa się $\mathrm{z}$ prowadnicy ślizgu (poz.1), która jest wykonana jako spawana. Prowadnica ślizgu współpracuje ze ślizgiem (poz.2), który jest wykonany jako spawany. Ślizg (poz.2) jest oparty na dwóch sprężynach (poz.3), które z kolei są rozmieszczone symetrycznie na prowadnicy ślizgu (poz.1), która jest przykręcona do ramy wózka za pomocą śrub z nakrętkami samozabezpieczającymi typu Vargal (poz.9). Celem zapewnienia luzu na ślizgach bocznych, który musi wynosić $20 \pm 1 \mathrm{~mm}$ dla pojazdu znajdującego się na torze wypoziomowanym, pomiędzy prowadnicą ślizgu poz.1 oraz ostojnicą wózka znajdują się podkładki regulacyjne (poz.8). Luz $20 \pm 1 \mathrm{~mm}$ musi występować pomiędzy odbijakiem (poz.4) i ślizgiem (poz.2) oraz rolką (poz.4) i wspornikiem na nadwoziu pojazdu. Na prowadnicy (poz.1) znajduja się wkładki z tworzywa sztucznego o własnościach wg dokumentu OW-1221. W celu ochrony ślizgu (poz.2) przed opadnięciem podczas rozłączania wózka i podnoszeniem nadwozia (względy BHP) jest on wyposażony w zabezpieczenie (poz.7) które zahacza o zaczep (poz.6).

Wariant II, (przedstawiony na rys.6) składa się $\mathrm{z}$ prowadnicy ślizgu (poz.1), która jest wykonana jako spawana. Prowadnica ślizgu (poz.1) współpracuje ze ślizgiem (poz.2), który wykonany jest jako spawany. Ślizg (poz.2) jest oparty na dwóch sprężynach (poz.3), które są z kolei rozmieszczone symetrycznie na prowadnicy ślizgu (poz.1). Prowadnica ślizgu (poz.1) jest przykręcona do ramy wózka za pomocą śrub z nakrętkami samozabezpieczajacymi (poz.9). Celem zapewnienia luzu na ślizgach bocznych, który musi wynosić $20 \pm 1 \mathrm{~mm}$ dla pojazdu znajdującego się na torze wypoziomowanym, pomiędzy prowadnicą ślizgu (poz.1) oraz ostojnicą wózka znajdują się podkładki regulacyjne (poz.8). Luz $20 \pm 1 \mathrm{~mm}$ musi występować pomiędzy odbijakiem (poz.4) i ślizgiem (poz.2). $\mathrm{Na}$ 
prowadnicy (poz.1) znajdują się wkładki z tworzywa sztucznego o własnościach wg dokumentu OW-1221. W celu ochrony ślizgu (poz.2) przed niekontrolowanym opadnięciem podczas rozłączenia wózka (względy BHP) jest on wyposażony w zabezpieczenie (poz.7), która zahacza o zaczep (poz.6).
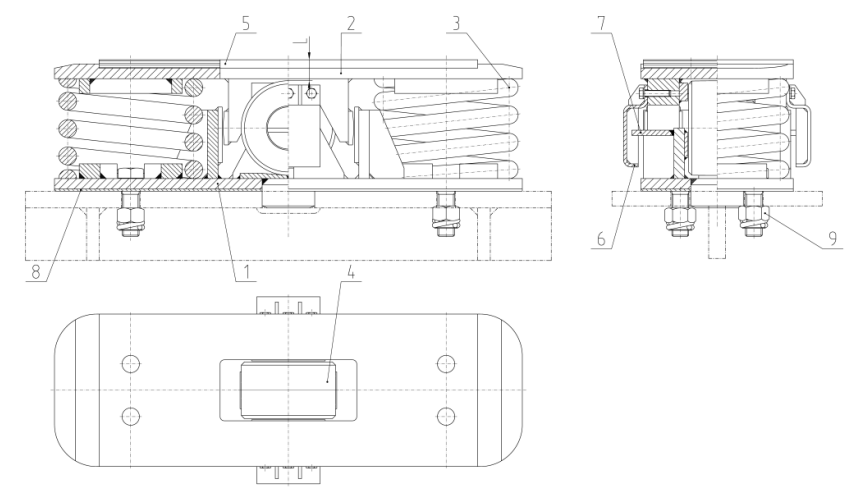

Legenda:

1 - Prowadnica ślizgu

2 - Ślizg

3 - Sprężyna

4 - Rolka

5 - Wktadka z tworzywa sztucznego

6 - Zabezpieczenie

7 - Zaczep

8 - Podktadka regulacyjna

9 - Nakrętka samozabepieczajaca

L - luz na ślizgach sprężystych

Rys. 5. Wariant I ślizgu sprężystego z rolką
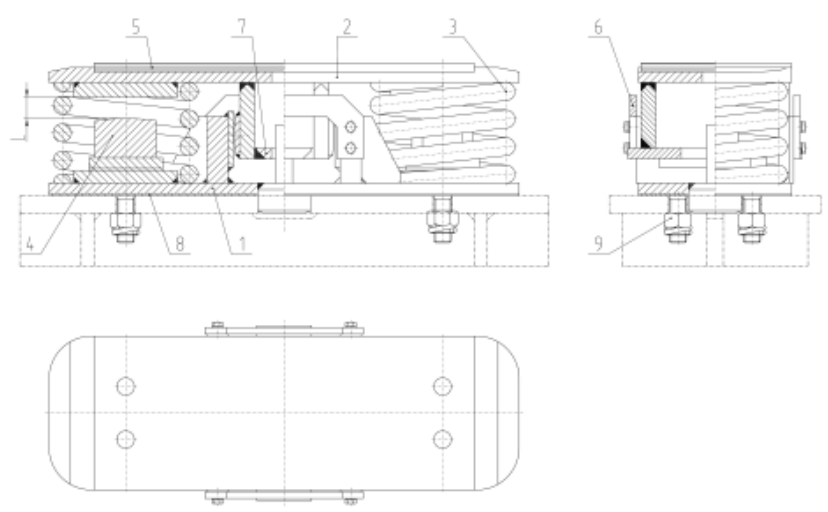

Legenda:

1 - Prowadnica ślizgu

2 - Ślizg

3 - Sprężyna

4 - Odbijak

5 - Wktadka z tworzywa sztucznego

6 - Zabezpieczenie

7 - Zaczep

8 - Podktadka regulacyjna

9 - Nakrętka samozabepieczajaca

L - luz na ślizgach sprężystych

Rys.6. Wariant II ślizgu sprężystego, opartego na klasycznej budowie, zaczerpniętej ze standardowych wózków dla wagonów towarowych

\subsubsection{Uziemienie wózka}

Wózek posiada uziemienie w postaci przewodu giętkiego łączącego każdą maźnicę z ramą wózka oraz przewodu łączącego ostoję wagonu $\mathrm{z}$ ramą wózka (rys.7). Przewód miedziany posiada przekrój poprzeczny $35 \mathrm{~mm}^{2}$ i musi zapewnić rezystancję $0,05 \Omega$ jak dla wagonów osobowych zgodnie z p.4.1 karty UIC 533 [4]. Zadaniem przewodu uziemiającego jest ochrona personelu podczas kontaktu z mechanicznymi częściami pojazdu, znajdującymi się chwilowo pod wysokim napięciem oraz niebezpiecznymi przeskokami łuku elektrycznego powstającymi w wyniku statycznych wyładowań. Niebezpieczeństwo to powstaje w wyniku usterek w elektrycznych urządzeniach pojazdu. Dodatkowo w celu zwiększenia ochrony personelu przed porażeniami elektrycznymi zamontowano dodatkowe przewody uziemiające pomiędzy korpusem maźnicy a korpusem prowadnicy. Każdy z przewodów o przekroju $35 \mathrm{~mm}^{2}$ jest wykonany z miedzi i przypada po jednym na oś zestawu kołowego (łącznie trzy na wózku). Dodatkowe przewody uziemiające są przedstawione na fotografii, zamieszczonej na rys.8.

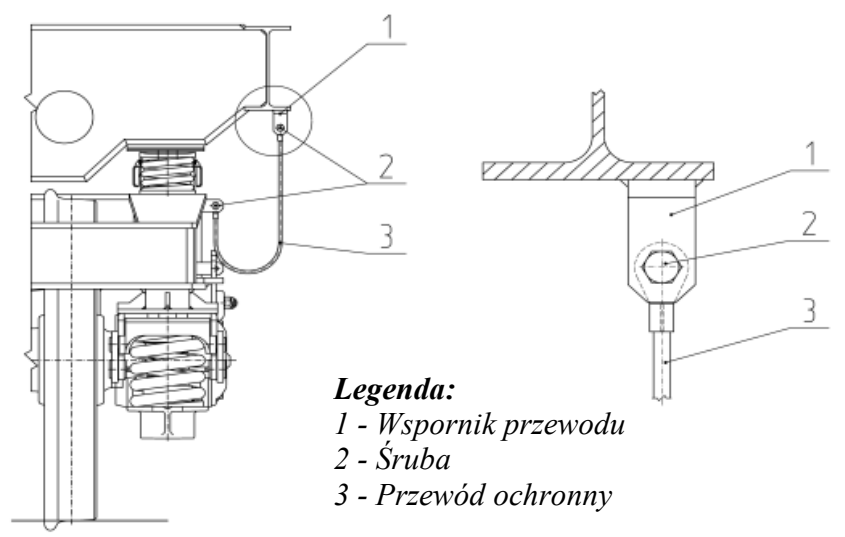

Rys.7. Uziemienie wózka. lewej strony przewód miedziany łączący wspornik na ostojnicy wózka ze wspornikiem

\subsubsection{Zestawy kołowe i maźnice}

Każdy wózek posiada po trzy zestawy kołowe przystosowane do przeniesienia nacisku na tor $20 \mathrm{t}$. Dwa skrajne zestawy kołowe wózka są zestawami napędnymi, natomiast środkowy zestaw jest zestawem tocznym. Zestaw kołowy jest wyposażony w koła monoblokowe o średnicy Ø920 mm w stanie nowym. Najmniejsza dopuszczalna średnica kół zużytych wynosi Ø860 mm.

Korpusy maźnic wykonane są ze staliwa 340$550 \mathrm{~W}$ o wytrzymałości na rozciaganie $\mathrm{Rm}=550 \div 700$ MPa wg normy PN-ISO 3755:1994 [6], posiadaja boczne oparcia sprężyn na których przyspawano prowadniki sprężyn. Konstrukcja maźnic umożliwia przyjmowanie obciążeń pionowych, poziomych i poprzecznych. 
Powierzchnie trące maźnic wykonano jako płytki z trudnościeralnej stali manganowej kategorii $\mathrm{E}$ wg karty UIC 893 [5].W maźnicach zastosowano łożyska walcowe typu NJ + NJP o wymiarach $130 \mathrm{x}$ 240 x 80. Maźnice uszczelnione są pierścieniem labiryntowym.

\section{CECHY INNOWACYJNE WÓZKA}

Do istotnych cech innowacyjnych wózka $33 \mathrm{MN}$ nalezą następujące rozwiązania konstrukcyjne:

- zastosowanie quasi-radialnego prowadzenia zestawów kołowych poprzez wprowadzenie luzów wzdłużnych $\mathrm{L}_{1}=9 \mathrm{~mm}$ na stronę, co znacznie zmniejsza kąty nabiegania na szynę

- zastosowanie hamulców tarczowych, zapewniających prawidłową intensywność hamowania, drogi hamowania jak również zredukowaną emisję hałasu do środowiska naturalnego

- zastosowanie dodatkowego uziemienia w obrębie zestawów kołowych, zabezpieczających obsługę pojazdu przed porażeniem
- wyeliminowanie resorów piórowych o zmiennej charakterystyce i zastosowanie sprężyn śrubowych, co korzystnie wpływa na bezpieczeństwo przed wykolejeniem

- zastosowanie sprawdzonego oparcia pudła za po-mocą gniazda skrętu oraz ślizgów sprężystych, które zostało zastosowane w układzie wózek-pudło w wagonach towarowych.

Aby wyznaczyć korzyści wynikające z zastosowania wózka trzyosiowego $\mathrm{z}$ radialnym prowadzeniem zestawów kołowych, wyznaczono promień łuku toru, który może przejechać pojazd. Zespołem determinującym ten przejazd jest wózek trzyosiowy 33MN. Usytuowanie narożnikowe wózka na tle luku toru o promieniu $\mathrm{R}$ przedstawiono na rys. 10 .

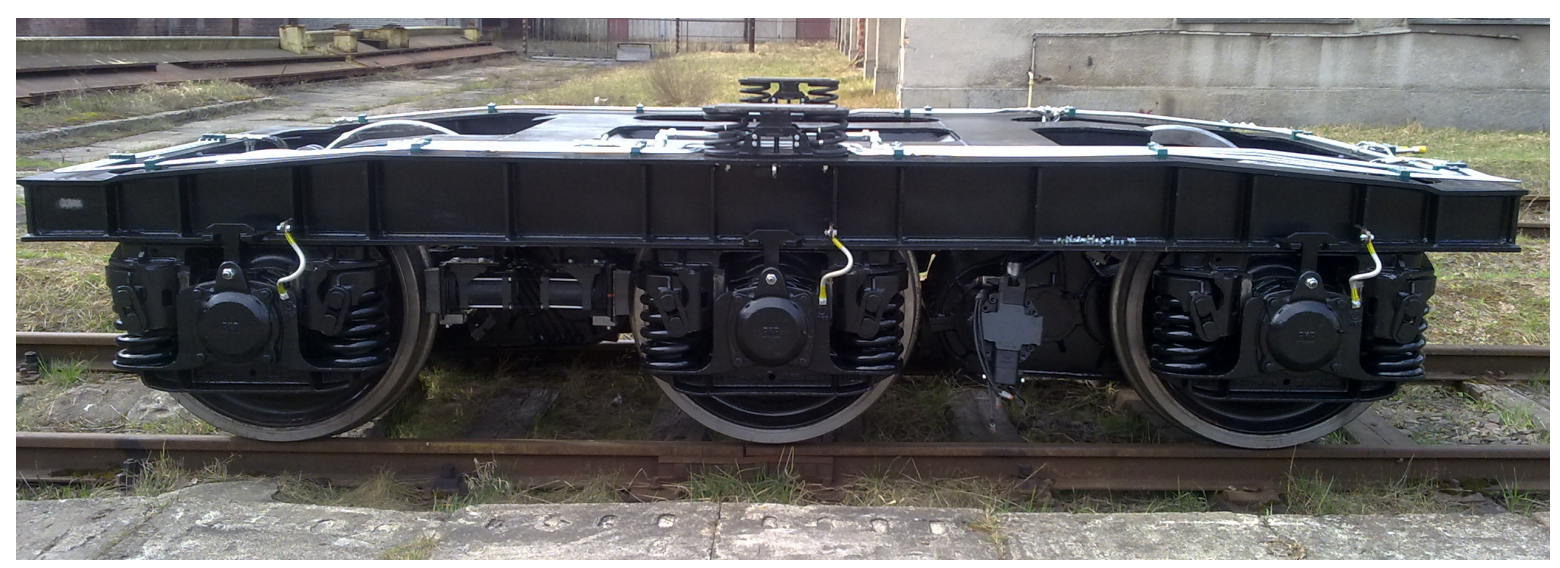

Rys.8. Widok z boku na wózek „33MN”. Między maźnicami a ostojnicami są zainstalowane dodatkowe przewody uziemiające.

Widok czoła wózka jest przedstawiony na fotografii, zamieszczonej na rys.9.

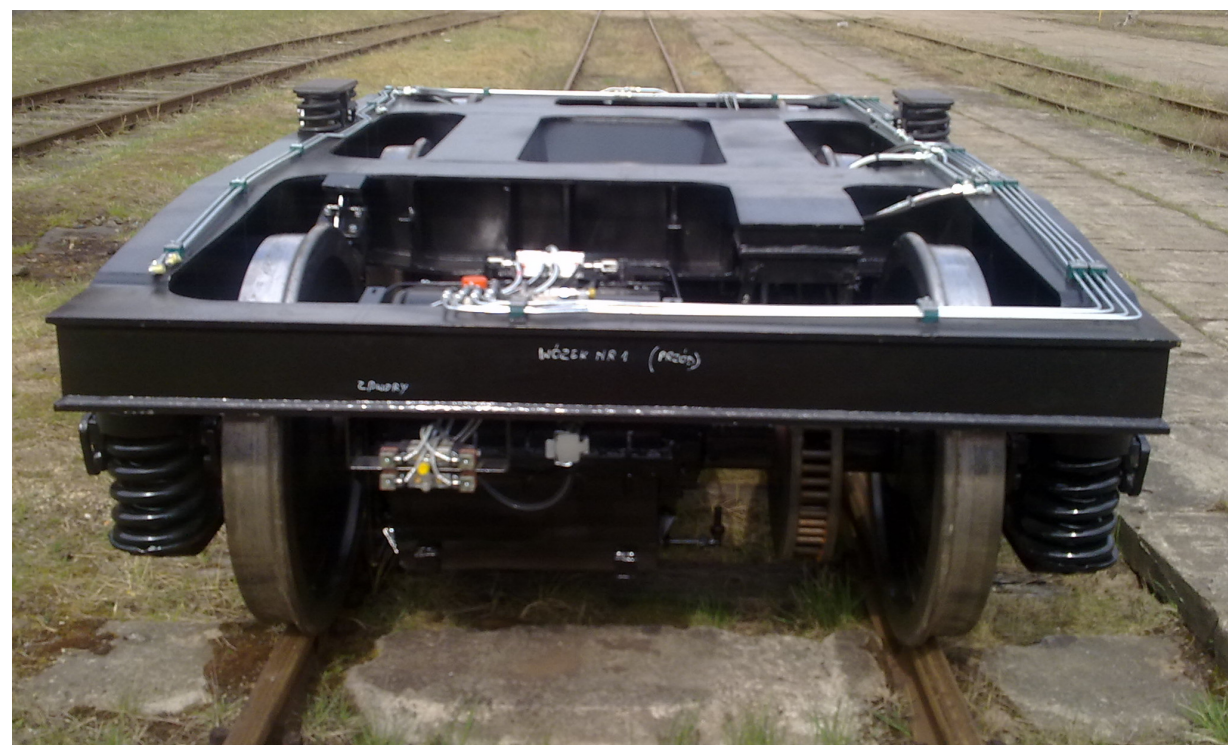

Rys.9. Widok czoła wózka 33MN. 


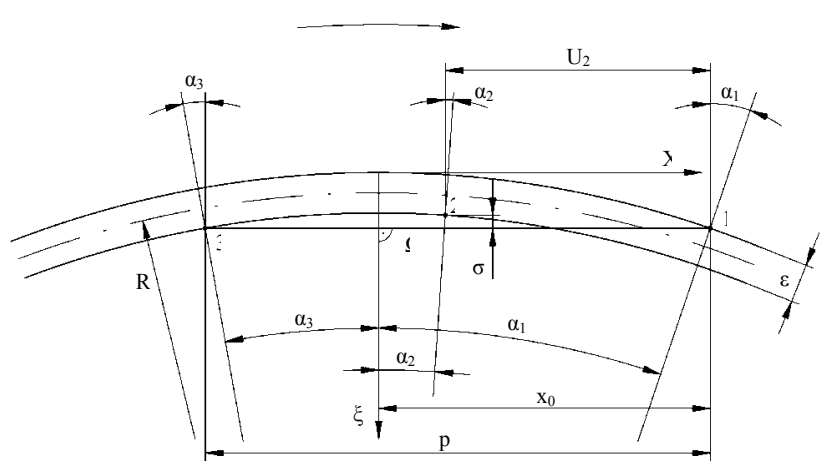

Rys.10. Usytuowanie wózka 33MN na łuku o promieniu R w położeniu narożnikowym.

Na rys.10 są następujące oznaczenia:

$\alpha_{1}$ - kąt nabiegania przedniego zestawu kołowego na szynę

$\alpha_{2}$ - kąt nabiegania środkowego zestawu kołowego na szynę

$\alpha_{3}$ - kąt nabiegania tylnego zestawu kołowego na szynę $\mathrm{x}_{0}$ - odstęp biegunowy

$\mathrm{R}$ - promień łuku toru

p- baza wózka

$\varepsilon$ - luz zestawu kołowego w torze

$Z$ rys.10 wynikają następujące zależności:

$$
\begin{gathered}
\sin \alpha_{1}=\frac{x_{0}}{R+\frac{\varepsilon}{2}} \\
\sin \alpha_{1}=\frac{x_{0}-\frac{p}{2}}{R-\frac{\varepsilon}{2}} \approx \frac{x_{0}-\frac{p}{2}}{R} \\
\alpha_{3}=\frac{x_{0}-p}{R}
\end{gathered}
$$

Po uproszczeniach kąty nabiegania wynoszą odpowiednio:

$$
\begin{gathered}
\sin \alpha_{1}=\alpha_{1}=\frac{x_{0}}{R} \\
\sin \alpha_{2} \approx \alpha_{2}=\frac{x_{0}-\frac{p}{2}}{R} \\
\sin \alpha_{3} \approx \alpha_{3}=\frac{x_{0}-p}{R}
\end{gathered}
$$

Odstęp biegunowy $\mathrm{x}_{0}$ można wyznaczyć ze wzoru:

$$
x_{0}=\frac{R \varepsilon}{p}+\frac{p}{2}
$$

Zgodnie z dokumentacją konstrukcyjną wielkość luzów przymaźnicznych $\mathrm{q}_{\mathrm{w}}=9 \mathrm{~mm}$ (luz na strone), natomiast 2s wynosi dla standardowych zawieszeń 2000 $\mathrm{mm}=2 \mathrm{~m}$.

Dla tego przypadku kąt $\Delta \propto$ wynosi odpowiednio:
$\Delta \propto=\operatorname{arctg} \frac{\mathrm{q}_{\mathrm{w}}}{\mathrm{s}}=\frac{0,009}{1}=0,009 \mathrm{rad}=0,515^{\circ}$

W związku z tym można uwzględnić w zależności (7) zmniejszenie kąta $\alpha_{1}$ o $\Delta \alpha$ przy założeniu, że dla małych katów obowiązuje $\sin \alpha_{1}=\alpha_{1}$ :

$$
\propto_{1}^{\prime}=\propto_{1}-\Delta \propto=\frac{\mathrm{x}_{0}}{\mathrm{R}+\frac{\varepsilon}{2}}-\frac{\mathrm{q}_{\mathrm{w}}}{\mathrm{s}}
$$

W punkcie B działa na główkę szyny siła kierująca P a nacisk pionowy koła na szynę $Q$ rozkłada się na punkt A i punkt B. Przy wzroście siły kierującej koło może się podnieść i opiera się na główce szyny tylko $\mathrm{W}$ punkcie B, w którym działa na główkę cały nacisk Q i siła kierująca P (rys. 11).

W przypadku ogólnym a zwłaszcza na łukach koło nabiega na szynę pod pewnym kątem określanym jako kąt nabiegania i wówczas punkt $\mathrm{B}$ znajduje się w pewnej odległości $\mu$ od osi zestawu kołowego (rys. 11).

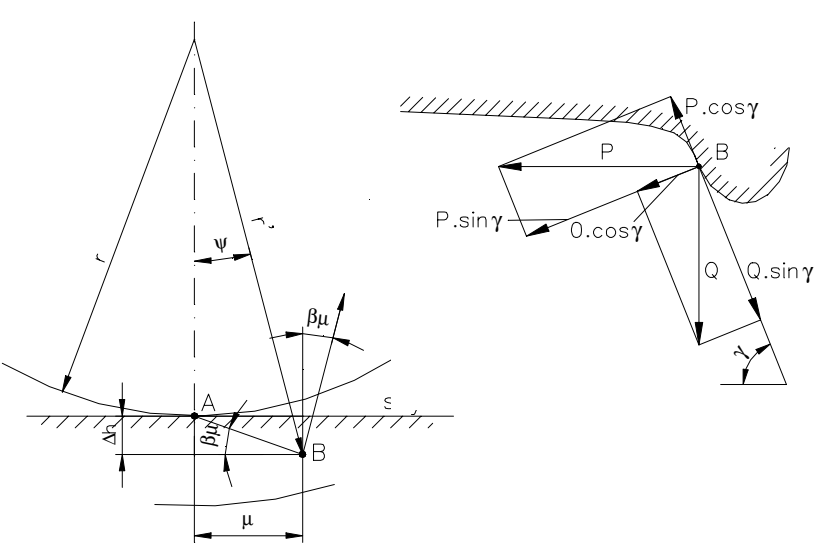

Rys.11. Siły działające w punkcie styku obrzeża z szyną

Z uwagi na niewielką stożkowatość powierzchni tocznej koła i niewielkie wartości kątów nabiegania można przyjąć, że gdy koło opiera się na główce szyny w dwóch punktach, to odległość $\Delta$ h punktu B od płaszczyzny toru jest stała i niezależna od kąta nabiegania. Przekrój poziomy powierzchni obrzeża przechodzący przez punkt B jest przekrojem stożka, którego wierzchołek znajduje się na osi zestawu kołowego a tworzące się nachylone pod kątem $\gamma$ do osi zestawu. Przekrój ten wyznacza zatem hiperbolę o równaniu:

$$
\frac{v^{2}}{v_{\mathrm{o}}^{2}}-\frac{\mu^{2}}{\mu_{0}^{2}}=1
$$

przy czym: $\mu_{0}=\gamma_{0} \cdot \operatorname{tg} \gamma$.

Różniczkując równanie hiperboli otrzymuje się:

$$
\frac{2 v \mathrm{~d} v}{v_{\mathrm{o}}{ }^{2}}-\frac{2 \mu \mathrm{d} \mu}{\mu_{0}{ }^{2}}=0
$$


Wyrażenie $\frac{\mathrm{d} v}{\mathrm{~d} \mu}$ jest tangensem nachylenia stycznej do hiperboli względem osi $\mu$.

Kąt nachylenia tej stycznej w punkcie B równa się kątowi nabiegania $\alpha$ koła na szynę, stąd:

$$
\frac{1}{\operatorname{tg}^{2} \gamma} \cdot \frac{\mu}{v}=\operatorname{tg} \propto
$$

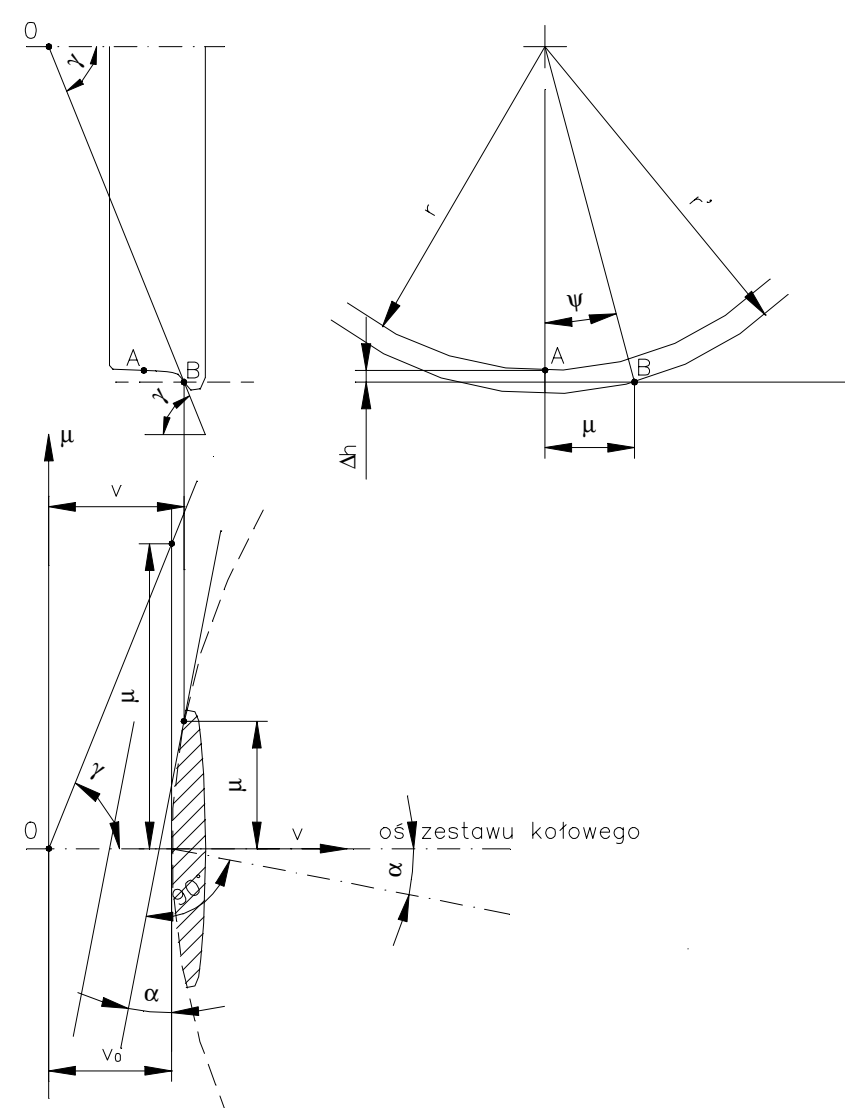

Rys.12. Skośne nabieganie koła na szynę

Współrzędne punktu B wynoszą:

$$
\mu=\mathrm{r}^{\prime} \cdot \sin \psi \text { i } v=\frac{\mathrm{r}^{\prime}}{\operatorname{tg} \gamma}
$$

Wstawiając te wartości w równanie (12) otrzymuje się zależność następującą:

$$
\sin \psi=\operatorname{tg} \propto \cdot \operatorname{tg} \gamma .
$$

Z Rys. 5 wynika następująca zależność na kąt $\Psi$ :

$$
\cos \Psi=\frac{r+\Delta h}{r+\Delta r}
$$

gdzie:

$\mathrm{r}=460 \mathrm{~mm}$ - promień toczny zestawu kołowego

$\Delta \mathrm{h}=10 \mathrm{~mm}$ i odpowiada punktowi na szynie, gdzie następuje styk obrzeża w punkcie $\mathrm{B}$

$\Delta \mathrm{r}=15,675 \mathrm{~mm}$ i odpowiada punktowi $\mathrm{F}_{1}$ na Rys. 6 wg karty UIC 510-2 [3]
Punkt $F_{1}$ jest punktem końcowym leżącym na prostej pochylonej pod kątem $70^{\circ}$ na obrzeżu, który może jeszcze zagwarantować styk koła z szyną. Zależność (15) można zapisać w sposób następujący:

$$
\sin (\arccos \Psi)=\operatorname{tg} \propto_{1}^{\prime} \cdot \operatorname{tg} \gamma
$$

Ponieważ dla małych katów można przyjąć $\operatorname{tg} \alpha_{1}{ }^{\prime}=\alpha_{1}$ wówczas otrzymuje się następującą zależność uwzględniając wzór (9) oraz (3):

$$
\sin \arccos \Psi=\left[\frac{\frac{\mathrm{R}(\varepsilon+2 \mathrm{q})}{\mathrm{p}}+\frac{\mathrm{p}}{2}}{\mathrm{R}+\frac{\varepsilon}{2}}-\frac{\mathrm{q}_{\mathrm{w}}}{\mathrm{s}}\right] \operatorname{tg} \gamma
$$

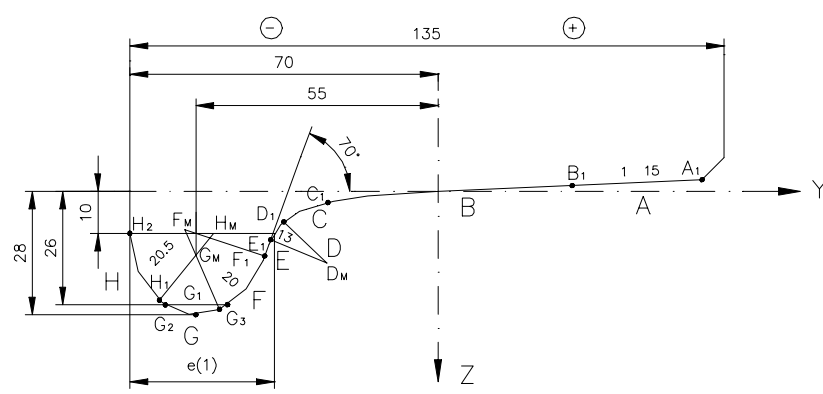

Rys.13. Zarys koła o średnicy tocznej $\phi 920$ zgodnie z kartą UIC $510-2[3]$

Z zależności (17) można wyznaczyć promień R:

$$
\mathrm{R}=\frac{\frac{\mathrm{p}}{2}-\left[\frac{\sin \operatorname{arc} \cos \psi}{\operatorname{tg} \gamma}+\frac{\mathrm{q}_{\mathrm{w}}}{\mathrm{s}}\right] \frac{\varepsilon}{2}}{\left(\frac{\sin \arccos \psi}{\operatorname{tg} \gamma}+\frac{\mathrm{q}_{\mathrm{w}}}{\mathrm{s}}-\frac{\varepsilon+2 \mathrm{q}}{\mathrm{p}}\right)}
$$

Po wstawieniu danych liczbowych do wzoru (18) tzn. $\mathrm{p}=3,2 \mathrm{~m}, \mathrm{q}_{\mathrm{w}}=0,009 \mathrm{~m}, 2 \mathrm{~s}=2,0 \mathrm{~m}, \gamma=70^{\circ}, \varepsilon=1,470$ $-1,410=0,06 \mathrm{~m}, \mathrm{q}=0,015 \mathrm{~m}$ otrzymuje się:

$$
\begin{gathered}
\mathrm{R}=\frac{1,6-\left[\frac{\sin \operatorname{arc} \cos \frac{460+10}{460+15,675}}{\operatorname{tg} 70^{\circ}}+\frac{0,009}{1,00}\right] \frac{0,060}{2}}{\left(\frac{\sin \operatorname{arc} \cos \frac{460+10}{460+15,675}}{\operatorname{tg} 70^{\circ}}+\frac{0,009}{1,00}-\frac{0,060+0,030}{10}\right)} \\
R=\frac{1,595379}{0,052866}=30,17 \mathrm{~m} .
\end{gathered}
$$

W takim przypadku można wyliczyć również kąt nabiegania wyznaczając najpierw odstęp biegunowy $\mathrm{x}_{0}$ na podstawie wzoru (3):

$$
\mathrm{x}_{0}=\frac{30,17(0,06+0,030)}{3,2}+1,6=2,448 \mathrm{~m} .
$$


Kąt nabiegania kół przedniego zestawu kołowego wynosi wykorzystując wzór (9):

$\alpha_{1}^{\prime}=\frac{2,448}{30,17+0,030}-\frac{0,009}{1,000}=0,072 \mathrm{rad} \approx 4,12^{0}$

Ponieważ luz zestawu kołowego w torze ,ع” jest wielkością bardzo małą $\mathrm{W}$ stosunku do promienia $\mathrm{R}$, to wówczas można skorzystać ze zmodyfikowanego wzoru (4):

$\sin \alpha_{1}^{\prime}=\alpha_{1}^{\prime}=\frac{x_{0}}{R}-\frac{q_{w}}{s}=\frac{2,448}{30,17}-\frac{0,009}{1}=0,072 \mathrm{rad} \approx 4,12^{0}$

Analogicznie można wyznaczyć kąty nabiegania dla kół środkowego zestawu kołowego:

$\sin \alpha_{2} \approx \alpha_{2}=\frac{x_{0}-\frac{p}{2}}{R}-\frac{q_{w}}{s}=\frac{2,448-1,6}{30,17}-\frac{0,009}{1}=0,019 \mathrm{rad}=1,09^{\circ}$

oraz tylnego zestawu kołowego:

$\sin \alpha_{3} \approx \alpha_{3}=\frac{x_{0}-p}{R}-\frac{q_{w}}{s}=\frac{2,448-3,2}{30,17}-\frac{0,009}{1}=-0,033 \mathrm{rad}=-1,94^{0}$

\section{WNIOSKI}

1. Wózek 33MN posiada możliwość przejazdu przez łuki o promieniu $\mathrm{R}=30 \mathrm{~m}$, co stanowi zapas w stosun$\mathrm{ku}$ do wymagania postawionego w Specyfikacjach Wymagań [9], gdzie wymieniony jest promień $\mathrm{R}=75$ m. Należy podkreślić, że o możliwości przejazdu oczyszczarki pojazdu OT-84 decyduje w dużej mierze układ biegowy. Aby w pełni sprawdzić możliwości przejazdu przez łuk o promieniu $\mathrm{R}=30 \mathrm{~m}$, należałoby sprawdzić inne parametry jak kąt obrotu wózka względem pojazdu. Im mniejszy promień łuku toru tym większy kąt obrotu, który może doprowadzić do wzajemnych kolizji pomiędzy elementami nadwozia i elementami wózka. Ważnym zagadnieniem podczas przejazdu oczyszczarki przez łuki toru o najmniejszym promieniu jest konieczność ,zachodzenia” na siebie powierzchni ślizgów. Zagadnienie to jest poruszone w karcie UIC 510-1 [2].

2. Układ biegowy $33 \mathrm{MN}$ posiada innowacyjne zawieszenie, które pozwala na quasi-radialne ustawianie się zestawów kołowych w łukach toru. Dzięki temu można liczyć się z tym, że:

- zużycie kół zestawów kołowych będzie mniejsze niż w pojazdach z tradycyjnym zawieszeniem

- mniejsza emisja hałasu do środowiska naturalnego oraz

- większe bezpieczeństwo jazdy, wskutek mniejszej siły prowadzącej i mniejszych kątów nabiegania.

\section{LITERATURA}

[1] Karta UIC 505-1: Pojazdy kolejowe. Skrajnia pojazdów.10-te wydanie z maja 2006.

[2] Karta UIC 510-1: Wagony towarowe. Układ biegowy. Normalizacja. 9-te wydanie z 1.01.1978. 14 zmian od 1.01.1980 do 1.01.1997

[3] Karta UIC 510-2: Pojazdy doczepne. Warunki dla stosowania kót o różnych średnicach $w$ układach biegowych różnego typu. 4-te wydanie z października 2002 do kwietnia 2004.

[4] Karta UIC 533:Pojazdy, uziemienie ochronne części metalowych. 3-cie wydanie. Kwiecień 2011.

[5] Karta UIC 893: Warunki techniczne dla dostawy blach na plyty prowadnicowe ze stali manganowej . 2-gie wydanie, czerwiec 2004.

[6] PN-ISO 3755:1994: Staliwo węlowe ogólnego przeznaczenia. Październik 1994.

[7] PN-EN 10089:2005:Stale walcowane na gorace na sprężyny ulepszane cieplnie. Warunki techniczne dostawy.

[8] OW-1221: Opis techniczny. Wózki dwuosiowe Nr 1204 0005. Program dopuszczenia wkładek $z$ tworzywa sztucznego do gniazd skrętu i plyt ślizgowych z tworzywa sztucznego dla ślizgów bocznych wagonów towarowych z wózkami dwuosiowymi. Listopad 1985 (niem. „Lastenheft für die Zulassung von KunstoffDrehpfanneneinlagen und Kunstoff-Gleitelementen für die seitliche Wagenkastenabstützung für Güterwagen mit Drehgestellen mit 2 Radsätzen").

[9] Opracowanie nr OT.00-70-0.: Opis techniczny oczyszczarki tłucznia typu OT-84.00. Stargard Szczeciński 02.2010 . 